AIAA-2002-0718

\title{
PHOTOVOLTAIC POWER FOR FUTURE NASA MISSIONS
}

\author{
Geoffrey A. Landis' and Sheila G. Bailey ${ }^{2}$ \\ NASA John Glenn Research Center \\ Mailstop 302-1 \\ 21000 Brookpark Road \\ Cleveland, $\mathrm{OH} 44135$
}

\begin{abstract}
Recent advances in crystalline solar cell technology are reviewed. Dual-junction and triplejunction solar cells are presently available from several U. S. vendors. Commercially available triple-junction cells consisting of $\mathrm{GaInP}, \mathrm{GaAs}$, and Ge layers can produce up to $27 \%$ conversion efficiency in production lots. Technology status and performance figures of merit for currentlyavailable photovoltaic arrays are discussed. Three specific NASA mission applications are discussed in detail: Mars surface applications, high temperature solar cell applications, and integrated microelectronic power supplies for nanosatellites.
\end{abstract}

\section{INTRODUCTION}

Since the launch of Vanguard, photovoltaic power has been the main electrical power source for space probes. Future space missions will require increasing amounts of power, and will require advanced power sources to accommodate the smaller, lighter and lower cost missions.
The required photovoltaic power technology will be different for different mission objectives relative to the sun. Near sun missions, including missions to Venus, Mercury, and the solar vicinity ("solar probe") will require solar technology which is optimized for high solar intensity and does not lose performance at high temperatures. Earth, Mars and asteroid missions require solar technologies that deliver high specific power and high efficiency at moderate light levels and temperatures. Outer planet missions will require new photovoltaic technologies that deliver power at extremely low light levels and temperatures. Finally, solar electric propulsion using ion engines or advanced forms of electric propulsion gives new challenges to the technology, requiring high power levels and extremely low weight.

Design rules for solar arrays are presented in reference [1]. Reviews of space solar cell technology can be found in references [2-5]. In this paper, we briefly review the current status of crystalline semiconductor photovoltaic cells and arrays, and then discuss three NASA mission applications in detail: Mars surface power, high temperature solar cell applications, and integrated microelectronic power supplies for nanosatellites.

\footnotetext{
'Engineer, Photovoltaics and Space Environmental Effects Branch, NASA John Glenn Research Center. Associate fellow, AIAA

${ }^{2}$ Engineer, Photovoltaics and Space Environmental Effects Branch, NASA John Glenn Research Center. Associate fellow, AIAA

Copyright $\mathbb{C} 2002$ by the American Institute of Aeronautics and Astronautics, Inc. No copyright is asserted in the United States under Title 17, U. S. Code. The U. S. Government has a royalty-free license to exercise all rights under the copyright claimed herein for Government purposes. All other rights are reserved by the copyright holder.
}

This is a preprint or reprint of a paper intended for presentation at a conference. Because changes may be made before formal publication, this is made available with the understanding that it will not be cited or reproduced without the permission of the author. 


\section{TECHNOLOGY ASSESSMENT}

Five different figures of merit are of importance for power supply comparison and assessment:

- Efficiency or power per unit area $\left(\mathrm{W} / \mathrm{m}^{2}\right)$

- Specific power (power per unit weight, $W / \mathrm{kg}$ )

- Cost per unit power $(\$ / W)$

- Moment of Inertia $\left(\mathrm{kg}-\mathrm{m}^{2}\right)$

- Stowed volume $\left(\mathrm{m}^{3} / \mathrm{W}\right)$

Array figures of merit are usually tabulated for conditions of $1 \mathrm{AU}$ from the sun ("AM0" intensity and spectrum) and $25 \mathrm{C}$. Trade studies have shown that even extremely high array costs can be worth the investment when they result in lower array weight.

\section{Cell Efficiency}

Photovoltaics have achieved dramatic improvements in cell efficiency. A recentlydeveloped solar cell uses a GaInP high-bandgap cell grown on a GaAs low-bandgap cell. This technology is variously referred to as galliumindium phosphide, GaInP/GaAs, InGaP, $\mathrm{Ga}_{0.5} \mathrm{In}_{0.5} \mathrm{P}$, as "dual junction" or "cascade" cells. The $1.85 \mathrm{eV}$ GaInP converts short wavelength photons, and GaAs converts lower energy photons. Newer solar cells add a third, lower bandgap junction, and four junction cells are being developed.

Dual-junction and triple-junction solar cells are presently available from several U. S. vendors. Commercially available dual-junction solar cells are $21-22 \%$ efficient. Currently, triple-junction cells consisting of $\mathrm{GaInP}, \mathrm{GaAs}$, and $\mathrm{Ge}$, are grown in series-connected layers, and are up to $27 \%$ efficient in production lots. These high-efficiency cells were developed under the programs funded primarily by the NREL, Air Force, and NASA.

Table 1 shows the efficiency achievable from commercially available solar cells.

Solar cell efficiency for commercial triple junction cells is now of the order of $26.5 \%$ to $27 \%$ efficient under test conditions at AM0, with laboratory cells tested at $29 \%$. However, actual performance in space at the array level is typically lower than performance in the laboratory, at the cell level. The table below shows a typical example of corrections that must be applied to calculate in-space end of life output for a typical operating array in Earth orbit. The net result is that a cell producing an efficiency of $26 \%$ under laboratory conditions will result in an achieved array efficiency of only $16.6 \%$ in operation.

In addition to these corrections, shadowing losses if any, wiring resistance, peak power tracking mismatch, voltage conversion electronics losses, battery charge/discharge unit electronics efficiency, and battery efficiency must be taken into account to calculate the amount of power available to the user.

Table 1. Commercially available solar cell voltage and efficiency under space (AM0) illumination

\begin{tabular}{|l|l|l|}
\hline Cell technology & AM0 Efficiency & Cell voltage \\
\hline Crystal Silicon & $13-14.8 \%$ & $0.5 \mathrm{~V}$ \\
\hline Amorphous Si & $5-7 \%$ & $\begin{array}{l}\text { Variable } \\
\text { (monolithic } \\
\text { series) }\end{array}$ \\
\hline $\begin{array}{l}\text { High Efficiency } \\
\text { Silicon }\end{array}$ & $16.6 \%$ & $0.55 \mathrm{~V}$ \\
\hline $\begin{array}{l}\text { Single Junction } \\
\text { GaAs/Ge }\end{array}$ & $19 \%$ & $0.90 \mathrm{~V}$ \\
\hline $\begin{array}{l}\text { Dual Junction } \\
\text { GaAs/GaInP }\end{array}$ & $22 \%$ & $2.06 \mathrm{~V}$ \\
\hline $\begin{array}{l}\text { 3 Junction } \\
\text { GaAs/GaInP/Ge }\end{array}$ & $26.8 \%$ & $2.26 \mathrm{~V}$ \\
\hline
\end{tabular}

Table 2: Typical correction factors to calculate power produced in space at the array level from power measured at cell level in laboratory

\begin{tabular}{|l|l|}
\hline Effect & loss \\
\hline Assembly loss in array & $-2.5 \%$ \\
\hline $85 \%$ packing factor & $-15 \%$ \\
\hline $\begin{array}{l}\text { Radiation Damage (end of life, after } \\
5 \times 10^{14} \text { 1-Mev Electrons) }\end{array}$ & $-8 \%$ \\
\hline $\begin{array}{l}\text { Temperature correction }\left(28^{\circ} \mathrm{C} \text { lab to }\right. \\
75^{\circ} \mathrm{C} \text { in space); } 0.19 \% / \mathrm{C}\end{array}$ & $-9 \%$ \\
\hline Surface contamination & $-1 \%$ \\
\hline Ultraviolet Damage $(-1.5-2.0 \%)$ & $-1.7 \%$ \\
\hline Micrometeorite Losses (estimate) & $-1 \%$ \\
\hline Thermal Cycling Losses (per year) & $-.25 \%$ \\
\hline Measurement Error & $-2 \%$ \\
\hline Aphelion distance (July) & $-3.25 \%$ \\
\hline Off-pointing correction & $-1 \%$ \\
\hline Total corrections to power & $-37.3 \%$ \\
\hline
\end{tabular}

2 


\section{Specific power}

Many arrays presently in space produce between 20 and $40 \mathrm{~W} / \mathrm{kg}$. The best state-of-the-art arrays that fly on some commercial communication spacecraft produce about $70 \mathrm{~W} / \mathrm{kg}$.

One fully qualified solar array, fabricated by AEC Able, has produced slightly more than 100 $\mathrm{W} / \mathrm{kg}$. That array, known by the trade name of "Ultra-flex," was made for the Mars-2001 Surveyor Lander spacecraft, which was cancelled. The substitution of multi-junction solar cells for the silicon solar cells on the Mars-2001 array would raise that array to about $150 \mathrm{~W} / \mathrm{kg}$, although some of this would be offset for a Mars surface application by the need to increase structural mass to meet strength requirements. This is not necessarily a simple upgrade because of the difficulty in combining the relatively fragile multijunction cells with the flexible substrate of the array.

\section{Array Cost}

Solar array costs have been analyzed in a study by E. Gaddy of NASA Goddard Space Center (GSFC) of the costs of flight panels purchased for GSFC missions. Costs include the photovoltaic panels with coverglass, interconnects, string terminations, temperature sensors, harness, diode boards, and diodes, and does not include costs for substrates, deployment mechanisms, launch tiedowns and snubbers, and solar array tracking. The costs include a qualification coupon vibrated and thermal cycled, and the cost of thermal vacuum and acoustic tests on the flight arrays. Costs run from a low of $\$ 588$ per watt to a high of $\$ 7415$ per watt, at test conditions. Average price was $\$ 1,794$ per watt at test conditions, and $\$ 2,544$ per watt under space operation conditions at end of life (see table in previous paragraph).

These costs represent data from roughly 1990 to 1998. Anecdotal reports testify that prices have dropped very roughly $40 \%$ since this study. Thus, prices are now estimated at about $\$ 1,100$ per (testcondition) watt. The actual cost will also reflect the cost of engineering and development of the array. Use of designs with a heritage from previous missions, and production of multiple units of the same design, can reduce costs.

If the cost of the mechanics to stow and deploy the array is included, the price increases by roughly $50 \%$. So the cost of an array that includes substrates, deployment mechanisms, launch tiedowns and snubbers is about $\$ 1650$ per test condition watt, not including the solar array tracking drive.

\section{Thin Film Solar Cells}

A new technology for solar cells that is developing rapidly is the thin-film cell, consisting of a thin (typically one micro-meter) semiconductor layer, deposited on a substrate. For terrestrial applications, the thin film substrates are typically either glass or stainless-steel foil. The potential for space applications comes with the substitution of a thin foil or of a plastic substrate. Such thin-film cells could potentially have an specific power of a thousand watts per kilogram, or even higher, if the efficiency can reach reasonable values on thin substrates, and if array technology can also be improved. An additional advantage of thin-film technology is that the radiation tolerance of thin film cells is extremely high, as much as an order of magnitude higher than the radiation tolerance of single-crystal cells. Recently, amorphous silicon thin-film solar array has been space qualified by flight on the Mir space station [6].

Thin film cells for space are currently being developed by a number of researchers, and are the subject of several recent review articles, however, the technology is not currently ready for mission application, and will not be reviewed here.

\section{SOLAR CELLS FOR MARS}

The planet Mars has been a particular target of NASA planetary exploration, and all recent missions to Mars have been solar powered. The Mars surface environment is quite different from the orbital environment in which space solar arrays normally operate. Major differences of the Martian surface from operating conditions of Earth orbit are:
(1) suspended atmospheric dust
(2) low operating temperatures
(3) deposition of dust on the arrays
(4) wind loading
(5) peroxide components of the soil
(6) radiation
(7) low atmospheric pressure 
A discussion of solar cell issues specific to Mars operation is presented in reference [7].

The atmosphere of Mars carries a considerable amount of suspended dust. This dust reduces the intensity of sunlight on the surface. The amount of dust in the atmosphere is characterized by the optical depth $\tau$, which can vary from less than 0.4 to values greater than 4 , depending on the season, the latitude, and the presence of dust storms. The effect of dust on the solar intensity at the surface has been analyzed by several researchers [8]. The performance of test solar cells on the Pathfinder mission tends to confirms these calculations..

The spectrum at the surface of Mars is modified by the passage of light through the dust layer. The dust reduces the amount of short wavelengths light penetrating to the surface. The effect on longer wavelengths is less. An example calculation of the spectral transmission of the atmosphere, calculated using a simplified model of dust properties, is shown in figure 1.

A reduction in the blue light shifts the optimum choice of solar cell materials to favor lower bandgap semiconductors, which respond better to the red and IR.

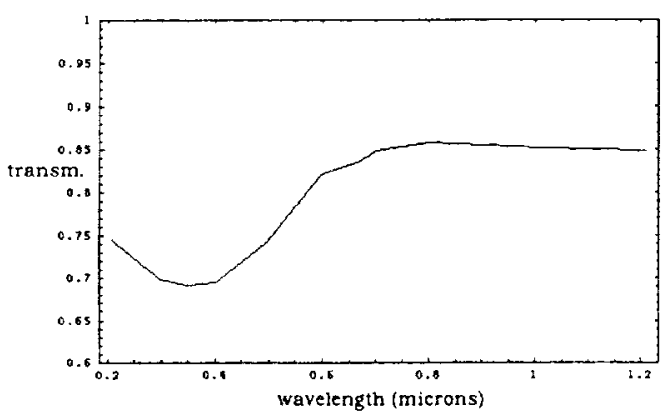

Figure 1: Typical transmission of the Mars atmosphere (theoretical). Transmission calculated at zenith angle of 0 (sun directly overhead) for $\tau=1$.

The spectrum will vary with time of day as the path length of light through the atmosphere changes, shifting toward the red during morning and afternoon operation. The spectral shift is important to solar cell design due to the fact that the highest efficiency solar cells use multiple junctions connected in series, which require a current matching of several sub-cells of different materials. This matching is depends on the spectrum.
The amount of dust in the Martian atmosphere varies with the presence of dust storms. Dust storms can be local, lasting only hours to days, can be regional, or can be global in extend, extending for up to a hundred days in duration. The global dust storm are seasonal, and occur only during the southern hemisphere summer (although not every summer will have such a dust storm.)

Since the sky of Mars scatters light, the sunlight comes from a range of angles, rather than in a straight line from the sun. Concentration devices such as mirrors or lenses will be much effective, and the efficiency of concentration devices will be worst at the highest dust loading. It also means that physical spectrum-splitting devices such as prisms or gratings will probably be not be effective on Mars.

Mars temperatures are lower than the standard test temperature. The effect of this is to shift the technology choice toward lower bandgap semiconductors. The temperature coefficient of a solar cell depends on the detailed shape of the spectrum near the energy bandgap of the material. This effect is important to current-matched multijunction cells, since the current matching will be sensitive to spectrum and to temperature. The spectral dependence makes temperature coefficients difficult to measure with simulated sunlight.

A particular difficulty is encountered with low temperature operation of some types of multijunction solar cells, including cascade cells and multi-junction amorphous cells. The interconnection between the individual elements of the cascade is typically done by use of a tunnel junction, which requires high doping levels to operate. Since dopant levels typically freeze out at low temperatures, the tunnel junction resistance can have a strong dependence on temperature, and in some cases can increase significantly at low temperature, resulting in lower performance.

The atmospheric dust does not remain suspended in the atmosphere indefinitely, but deposits out of the atmosphere onto any horizontal surfaces. This dust deposits out of the atmosphere and onto any flat surface; the time scale for this settling is on the order of 100 days. A measurement on the Pathfinder mission (figure 2) indicated dust coverage rate of $0.3 \%$ power loss per day [9]. This degradation rate probably levels off with time, but the long-term trend is still highly debated. 
This is potentially the factor which limits the operating lifetime of a solar array on Mars, unless a technique is developed to periodically remove the dust. The worst-case scenario is that the lander is in the settling phase of a global dust storm. There can be one, and possibly two, global dust storms per Martian year, typically occurring near perihelion. In some years there are no global storms.

The dust deposition adds an additional red-shift the insolation received by the solar cell.

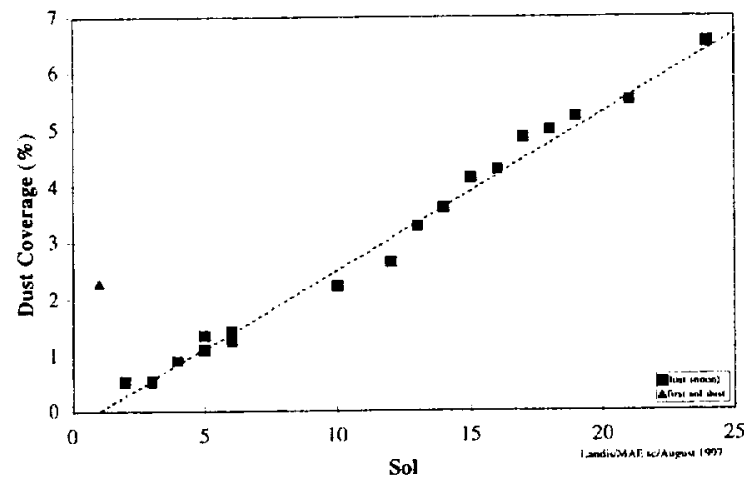

Figure 2: Dust coverage of the Sojourner Rover solar array. Data measured from the MAE experiment on the rover [data from Landis and Jenkins 9].

\section{HIGH SOLAR INTENSITIES}

Mission destinations with a need for high temperature, high intensity, and solar arrays include Mercury orbiters and landers, Venus orbital missions, and close encounters to the sun. For near-sun missions, solar power sources are ideal, since an abundant supply of solar energy is available. Paradoxically, however, the high solar intensity has a deleterious effect on solar cell performance, since the equilibrium temperatures of the solar arrays will also be high, and photovoltaic device performance typically decreases with temperature. Therefore, for these missions it will be desirable to develop solar cells with a low temperature dependence [10].

At least three missions have already flown and functioned well at high intensities: Pioneer Venus/Mercury, which reached $0.38 \mathrm{AU}$, Helios A, reached $0.31 \mathrm{AU}$; Helios $\mathrm{B}$, which reached 0.29 AU. All of these spacecraft used silicon cells that were slightly modified for high intensity use in conjunction with techniques to reduce the solar intensity on the array.

The NASA Discovery mission MESSENGER, a Mercury orbiter, is planned for travel to $0.31 \mathrm{AU}$. Its solar array design is currently under development. MESSENGER off points the array as the spacecraft nears the sun. The array is designed to tolerate pointing at the sun for a minimum of one hour, although it cannot function under these extremes. In normal operation the array operates as high as $130 \mathrm{C}$, if the off pointing fails, the array may point directly at the sun reaching a temperature of $260 \mathrm{C}$.

At perihelion, Mercury is only 0.307 astronomical units from the sun, and the solar intensity is 10.6 times the intensity in Earth orbit, 1.4 watts per square centimeter. The array on an orbiter also receives reflected sunlight, and infrared heating from Mercury. The worst case occurs when the satellite is between the sun and the planet, when the array receives full intensity of both albedo and infrared. The worst-case solar array for a Mercury orbiter must thus produce power at $425^{\circ} \mathrm{C}$. Operating at such a high solar intensity is a significant problem for power systems.

Solar probe is a mission that has been proposed as part of the "Fire and Ice" initiative $[11,12]$. This mission would operate even closer to the sun, at a minimum distance of 4 solar radii, and even higher operating temperatures. Thus, it would have an even more critical need for high-temperature power supplies.

\section{Conventional Solar Cells}

For a silicon array, power output changes by a factor of $-4.510^{-3}$ for each degree $\mathrm{K}$ over the standard test temperature $[13,14]$. Thus, a conventional silicon solar array would produce no power at all at the distance of Mercury. (The solar array for Mariner 10 was designed to reflect incident light away, and was not pointed directly toward the sun, to deal with this problem.)

A more advanced solar cell type is GaAs on Ge. For this cell type, power output decreases by $2 \cdot 10^{-3}$ per degree $\mathrm{K}[13,14]$. At $425^{\circ} \mathrm{C}$, the power loss is $80 \%$. In Mercury orbit a GaAs cell would produce only $20 \%$ of nominal power. An $18.5 \%$ efficient $\mathrm{GaAs}$ cell is only 3.7\% efficient at worstcase Mercury conditions. An efficiency of fewer 
than $4 \%$ is extremely poor. Thus, we would like to demonstrate that solar cell technology can be made that will operate at high temperatures.

(Techniques such as reflective sun-screens, pointing edgewise to the sun, or shading louvers can reduce temperature, but reduce the light reaching the cell, hence directly reducing the power.).

\section{High-temperature Cells}

The dual-junction or triple-junction solar-cell structure is highly efficient for cells operating near Earth, but the low bandgap elements of the cascade do not have low temperature coefficient. For high temperature operation, we will use this cell with the low-bandgap GaAs bottom cell left out.

GaInP cells should operate efficiently in the high temperature, high intensity environment of Mercury orbit. Figure 3 plots normalized temperature coefficients of various solar cell types as a function of bandgap. From this curve, we expect a GaInP $(1.85 \mathrm{eV})$ cell to have a normalized temperature coefficient of about $110^{-3}$ per degree $\mathrm{K}$, half that of GaAs. Thus, at Mercury orbit, the cell should produce $60 \%$ of nominal power. An $18 \%$ efficient GaInP cell will have $11 \%$ efficiency in Mercury orbit, or three times higher power than a GaAs solar cell.

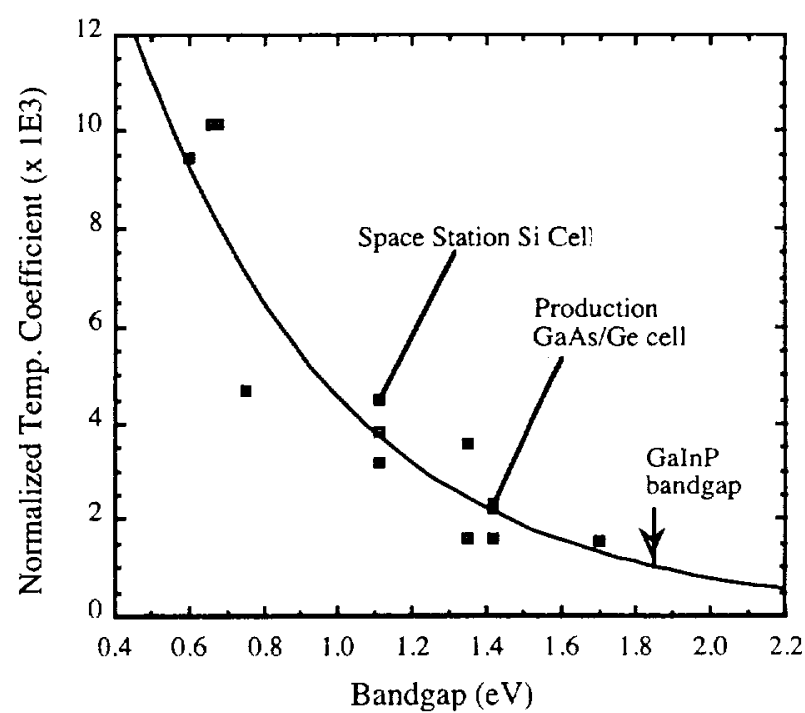

Figure 3. Normalized temperature coefficient $(1 / \mathrm{P} \mathrm{dP} / \mathrm{dT})$ as a function of cell bandgap [from 10]

\section{GaInP Cell Testing}

A $2 \times 2-\mathrm{cm} \mathrm{GalnP/Ge} \mathrm{cell} \mathrm{made} \mathrm{by} \mathrm{Tecstar} \mathrm{using}$ production processing was tested. The cell was placed on a hot plate in a Spectrolab X25 solar simulator and measured at 1 sun $\sim$ AMO. The cell was then heated and measured every 10 degrees to the maximum temperature that the equipment could reach. The variation of short circuit current $\left(I_{s c}\right)$, open circuit voltage $\left(V_{o c}\right)$, and fill-factor $(F F)$ with temperature are shown in figure 4 .

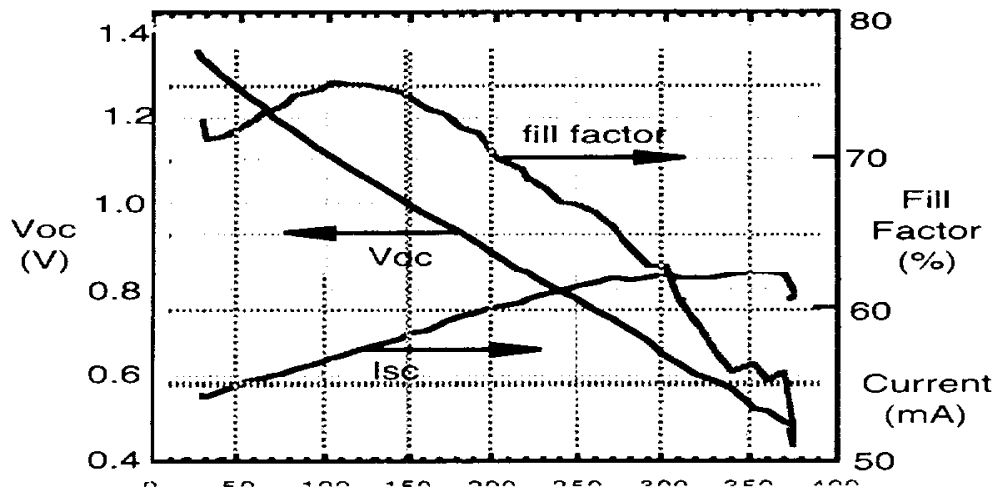

Figure 4. GaInP solar cell parameters measured as a function of temperature, from 0 to $400 \mathrm{C}$. Open circuit voltage and fill factor decrease with temperature, while the short circuit current shows a slight increase. 


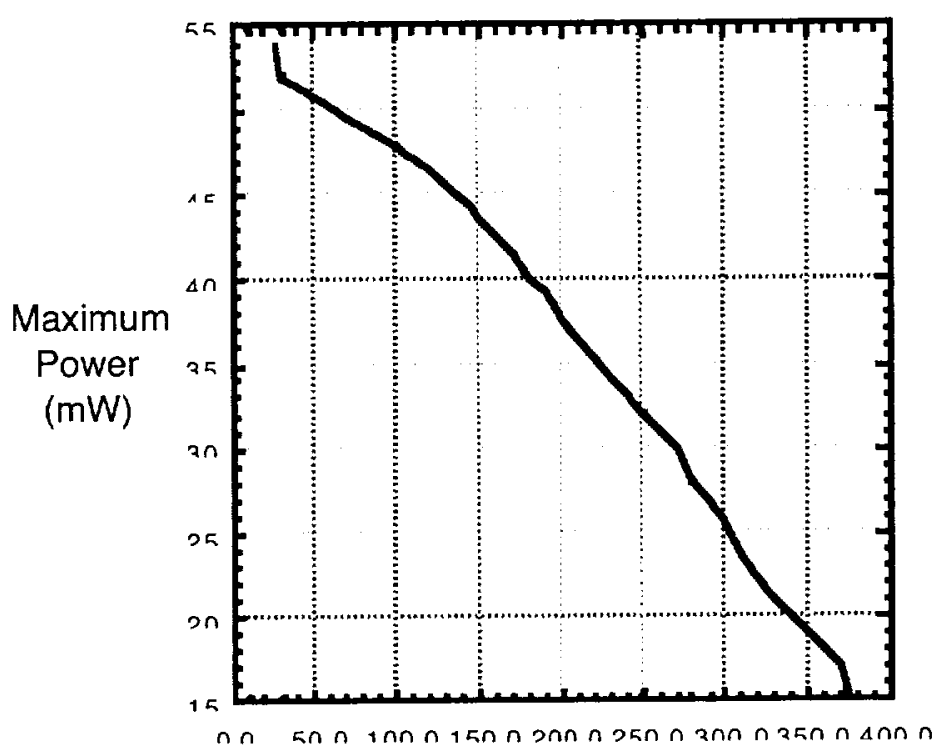

Figure 5. GaInP solar cell power output measured as a function of temperature, from 0 to $400 \mathrm{C}$. The power decrease is almost linear up to $370 \mathrm{C}$.

All of these graphs show the normal decrease in voltage and increased current with temperature up to around $275^{\circ} \mathrm{C}$. Above this point $\mathrm{l}_{\mathrm{sc}}$ tends to flatten and at higher temperatures decrease. The temperature variation of the maximum power of the cell is roughly linear with temperature up to about $275^{\circ} \mathrm{C}$, and decreases slightly faster above this. The linear degradation of temperature, figure 5 , corresponds to a linearized temperature coefficient of about $1.7710^{-3}$ per degree $K$, slightly higher than that expected from the bandgap if extrapolated from figure 1 . If this temperature coefficient were linear, the cell would be expected to drop to zero power at roughly $590^{\circ} \mathrm{C}$, consistent with the expected value shown in figure 3 .

The high temperature portion of this curve indicates degradation of the cell. The short circuit current starts to degrade abruptly at $350^{\circ} \mathrm{C}$, accompanied by an abrupt drop in fill-factor. This decrease in the cell performance does not recover upon returning to room temperature, indicating permanent damage in the cell. The loss of fill factor indicates that the cell was shunted. This shunting occurred because the contact metallization in the cell is failing. At elevated temperatures, the contact metallization can start to diffuse into the cell and eventually cause permanent damage.

\section{Degradation}

Careful study of the cell structure and effects of temperature can lead to improved contact metallization which results in cell survivability at elevated temperatures. Solar cell contacts have been developed to solve the high-temperature contact degradation of other types of solar cell.

The principal modifications to GaAs solar cells that improved high temperature survivability were changes to the contact metallization composition and the introduction of diffusion barriers. GaAs solar cells stable to $500^{\circ} \mathrm{C}$ are described by Tobin et al. [15]. Concentrator cells were produced that survived repeated 7 minute excursions to $600^{\circ} \mathrm{C}$ and showed only a $10 \%$ loss after a single exposure to $700^{\circ} \mathrm{C}$, and Spitzer et al. [16] report tests of a solar-cell contact system which is stable for excursions up to temperatures of $750^{\circ} \mathrm{C}$.

Applying these same methods to modern GaInP/Ge cells should be low risk since the growth of these cells occurs above $600 \mathrm{C}$. Nonetheless, the interaction between the metallization and the top cell must be checked. Diffusion barriers will also be required to prevent degradation of the semiconductor by loss of phosphorus.

One of the problems facing closer encounters to the sun is that the substrate adhesives weaken at 
high temperatures. Research is needed to identify and test adhesives that show promise of operating at higher temperatures than those encountered by the Helios and MESSENGER spacecraft, which are designed for approximately $0.3 \mathrm{AU}$.

Research may also be necessary to develop an entirely different type of substrate than those presently used, should temperatures finally exceed what is practical for low outgassing substrate adhesives.

Further research is required to use second surface mirrors directly on cells. In particular, the cover itself, with proper metallization, can serve as a combined second surface mirror and neutral density fulter.

Long term (i.e. several-year) exposures to the materials used in solar arrays in the high temperature high intensity range have not been adequately studied. For missions requiring such exposure, testing needs to be carried out to check for unexpected effects.

The increased operating temperatures near the sun may make it possible to realistically achieve some degree of annealing of cell radiation damage. Tests on solar cells and associated calculations are needed to determine whether this is practical for missions traveling close to the sun.

\section{Other materials: $\mathrm{SiC}$}

Another approach for high temperature conditions is to develop $\mathrm{SiC}$ solar cells. $\mathrm{SiC}$ is a semiconductor that is now being commercialized for high power, high temperature power electronics. The $\mathrm{SiC}$ material properties that make it attractive for these applications include the following: high bandgap, high thermal stability (> $700{ }^{\circ} \mathrm{C}$ ); high breakdown field strength; good radiation tolerance; high thermal conductivity; hardness.

The difficulties that exist presently are: micropipe defects; high dislocation densities, making the material unusable for solar cells; low carrier mobility; limited availability; and high cost.

Prototype $\mathrm{SiC}$ solar cells have been demonstrated at NASA Glenn [17], however, development of high efficiency $\mathrm{SiC}$ cells will require considerable effort.

$\mathrm{SiC}$ is clearly worthy of development investment due to its broad benefits in many areas of aircraft and space electronics.

\section{INTEGRATED MICROELECTRONIC POWER SUPPLIES}

The need for smaller lightweight autonomous power systems has recently increased with the increasing focus on micro- and nanosatellites [18]. Small area high-efficiency thin film batteries and solar cells are an attractive choice for such applications. The NASA Glenn Research Center has been working on the development of autonomous monolithic packages combining these elements or what are called integrated microelectronic power supplies (IMPS). These supplies can be combined with individual satellite components and are capable of providing continuous power in a variety of illumination schemes [19-21].

IMPS include devices for power generation, energy storage and power conditioning. So far, the IMPS created at NASA Glenn have been developed to meet the needs of microelectronic devices in space, such as Multi-Chip Modules (MCM) and MicroElectromechnical Systems (MEMS) [19]. The power requirements placed on an IMPS will play a large role in determining the ultimate size of the device. The voltage of the PV portion of the device is determined by the materials used. In the case of a GaAs homo-junction cell this will be around $1.0 \mathrm{~V}$ (table 1). For thin-film a-Si or $\mathrm{CuInSe}_{2}$ (CIS) PV, the voltage generated will be somewhat less (0.4-0.8 V). Through the use of monolithically interconnected modules (MIM), many junctions can be put together in series to increase the voltage. Unfortunately, the available current will always be a function of the active surface area of the device.

The voltage of a Li-ion battery is primarily determined by the material used in its cathode. A vanadium pentoxide or manganese oxide battery will have and open circuit voltage of $3.0 \mathrm{~V}$, whereas a nickel cobalt cell will be $4.2 \mathrm{~V}$. In a way similar to PV cells, Li battery cells can be connected in series configurations to produce different voltages. Volume determines the amount of energy that can be stored in a cell (i.e., capacity). The size also impacts the rate at which a battery can be charged and discharged: the smaller the battery, the smaller the charging and discharging currents it can handle).

Ideally, in order to minimize the control electronics associated with an IMPS, the photovoltaic array is designed such that its output 
voltage matches the voltage needs of the battery and its current output is sufficient to charge the battery while simultaneously providing power to the load. The precise sizing of the array and battery will also be dependent on the anticipated illumination cycle. For example, in a typical 90minute low-earth orbit (LEO) period, the battery will have to support the electrical load for 35 minutes of eclipse. During the 55 minute insolation (daylight) period, the solar array has to provide load power while fully re-charging the battery. Once the PV and battery are matched, the only additional components required are a blocking diode to prevent the battery from discharging through the PV array during eclipse.

The Li-ion batteries play a large role in determining the temperature regime in which these systems are suitable. Li-ion cells continue to deliver a sizeable fraction (i.e. $80 \%$ ) of their capacity at temperatures as low as $-20{ }^{\circ} \mathrm{C}$. Below such a temperature they do not perform well. However, they do not exhibit permanent damage if they are cycled between larger temperatures regimes (i.e., plus or minus $80^{\circ} \mathrm{C}$ ). Thin-film Liion batteries have been shown to operate well at temperatures up to $60^{\circ} \mathrm{C}$.

Some of the possible mission applications of integrated power supplies are discussed by Hoffman et al. [21].

\section{Starshine demonstration}

As a demonstration of the utility of an IMPS, NASA Glenn has developed IMPS supplies for an atmosphere research satellite, Starshine-3 (Ref 3). Starshine 3 is a micro-satellite $1.0 \mathrm{~m}$ in diameter with a mass of $88 \mathrm{~kg}$, designed to measured the drag in the upper earth atmosphere (Figure 6.) It includes $48-2-\mathrm{cm} \times 2-\mathrm{cm}$ triple junction solar cells manufactured by Emcore, and five integrated power supplies produced by NASA Glenn. It was launched on a Lockheed Martin Athena I booster from Kodiak Alaska on September 29, 2001 into a $67^{\circ}$ inclination low earth orbit.

The IMPS for Starshine, shown in Figure 7, combines a 7 -junction $/ 1-\mathrm{cm}^{2}$ monolithicallyinterconnected GaAs module (MIM) with a lithium ion battery [20]. The MIM we used in this case has more than enough voltage and current to both charge the Li ion and power the load. The IMPS incorporated a commercial Panasonic ML2020 rechargeable manganese dioxide $\mathrm{Li}$ ion battery [22]. This $3.0 \mathrm{~V}$ "coin cell" had a diameter of 2.0 $\mathrm{cm}$, thickness of $2.0 \mathrm{~mm}$, mass of $2.2 \mathrm{~g}$, and a nominal capacity of $45.0 \mathrm{mAh}$.

The first hundred days of performance data has shown that the IMPS power system has been performing as predicted, with full battery charging during eclipse. Longer flight duration will be required to quantify the rate of in-space degradation, if any.

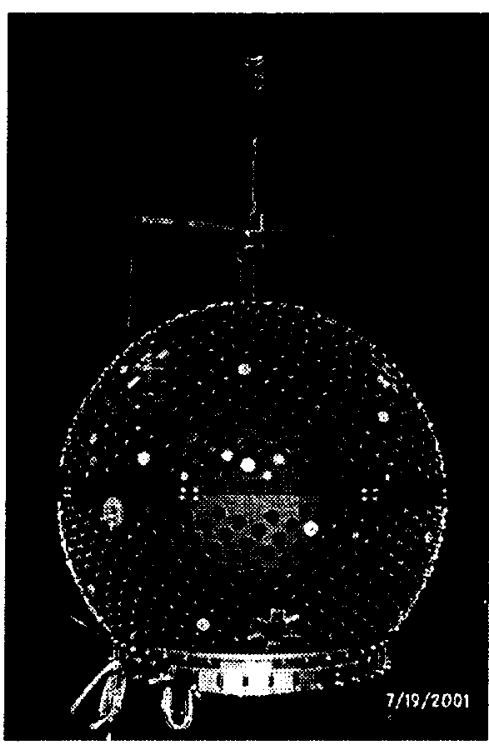

Figure 6: Starshine 3 micro-satellite.

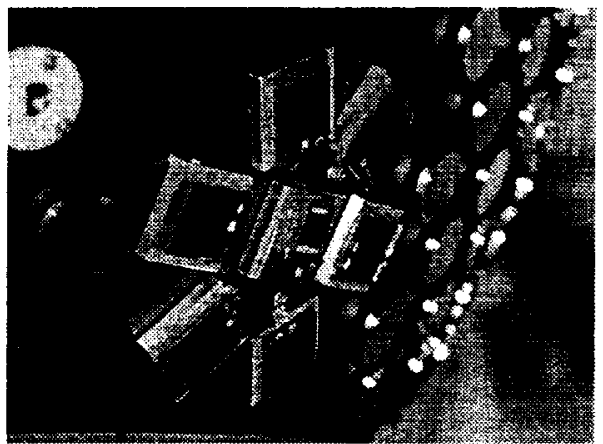

Figure 7: IMPS prototype with GaAs Monolithically-integrated cells and Panasonic battery mounted on the Starshine.

\section{CONCLUSIONS}

Photovoltaics have achieved dramatic improvements in cell efficiency. Recentlydeveloped solar cells, "dual junction" or "cascade" solar cells, are presently available from several 
U.S. vendors with $21-22 \%$ efficiency. Triplejunction cells are up to $27 \%$ efficient in production lots.

For mission application, a number of different figures of merit are important. Three specific NASA applications were considered: Mars, nearsun missions, and the integrated microelectronic power system for nanosatellites.
Further development of photovoltaic technology is important if cell technology is to be developed for future NASA missions. Recently NASA appointed a technical assessment team of photovoltaic power experts and power system engineers to analyze the state of the art in photovoltaic technology and recommend a program of improvement designed to achieve NASA requirements [23]. Table 3 summarizes the main conclusions and recommendations of this team.

Table 3. Comparison of technology requirements with state of the art

\begin{tabular}{|c|c|c|c|c|}
\hline Technology & Driving missions & Requirements & State of the art & Needed program \\
\hline $\begin{array}{l}\text { High Power } \\
\text { Arrays for Solar } \\
\text { Electric } \\
\text { Propulsion } \\
\text { (SEP) }\end{array}$ & $\begin{array}{l}\text { Comet sample } \\
\text { return, outer } \\
\text { planet missions, } \\
\text { Mars Sample } \\
\text { Return } \\
\end{array}$ & $\begin{array}{l}\cdot>150 \mathrm{~W} / \mathrm{kg} \text { specific } \\
\text { power } \\
\text { - operate to } 5 \mathrm{AU}\end{array}$ & $\begin{array}{l}\cdot 50-100 \mathrm{~W} / \mathrm{kg} \\
\text {-unknown LILT } \\
\text { effect }\end{array}$ & $\begin{array}{l}\text { - Thin-film cells } \\
\text { - Low mass and cost cells } \\
\text { and arrays } \\
\text { - Hi efficiency cells }\end{array}$ \\
\hline $\begin{array}{l}\text { Electrostatically } \\
\text { Clean Arrays }\end{array}$ & $\begin{array}{l}\text { SEC missions: } \\
\text { MMS, MC GEC, } \\
\text { SP, Sentinels }\end{array}$ & $\begin{array}{l}\cdot<120 \% \text { of the cost of } \\
\text { a conventional array }\end{array}$ & $\begin{array}{l}-~ 300 \% \text { of the } \\
\text { cost of a } \\
\text { conventional array }\end{array}$ & $\begin{array}{l}\text { - Transparent plastic covers } \\
\text { - Glass covers for multiple } \\
\text { cells }\end{array}$ \\
\hline Mars Arrays & $\begin{array}{l}\text { Mars surface } \\
\text { missions and } \\
\text { rovers, Mars } \\
\text { Sample Return, } \\
\text { Scouts }\end{array}$ & $\begin{array}{l}-26 \% \text { efficiency } \\
\cdot>180 \text { sols } @ 90 \% \text { of } \\
\text { full power }\end{array}$ & $\begin{array}{l}\cdot 24 \% \\
\cdot 90 \text { sols @ } 80 \% \\
\text { of full power }\end{array}$ & $\begin{array}{l}\text { - Optimized cells for Mars } \\
\text { - Dust mitigation }\end{array}$ \\
\hline $\begin{array}{l}\text { High } \\
\text { Temperature } \\
\text { Solar Arrays }\end{array}$ & $\begin{array}{l}\text { Solar Probe, } \\
\text { Mercury, Venus, } \\
\text { Sentinels, PASO }\end{array}$ & $\begin{array}{l}-\geq 350^{\circ} \mathrm{C} \text { operation } \\
\text { (higher temperatures } \\
\text { reduce risk and } \\
\text { enhance missions) }\end{array}$ & $\begin{array}{l}-130^{\circ} \mathrm{C} \text { steady } \\
\text { state; } 260^{\circ} \mathrm{C} \text { for } \\
\text { short periods }\end{array}$ & $\begin{array}{l}\text { - Adapt cells and arrays to } \\
\text { high temperatures based } \\
\text { on AFRL technology }\end{array}$ \\
\hline $\begin{array}{l}\text { High Efficiency } \\
\text { Cells }\end{array}$ & All missions & $\cdot 30+\%$ & $\cdot 27 \%$ & $\begin{array}{l}\text { - Adapt AFRL and } \\
\text { commercial progress to } \\
\text { NASA needs }\end{array}$ \\
\hline $\begin{array}{l}\text { LILT Resistant } \\
\text { Arrays }\end{array}$ & $\begin{array}{l}\text { Outer planet } \\
\text { missions, Solar } \\
\text { Electric } \\
\text { Propulsion } \\
\text { missions }\end{array}$ & $\begin{array}{l}\text { - No reduction of power } \\
\text { under LILT conditions }\end{array}$ & $\begin{array}{l}\text { - Uncertain } \\
\text { behavior of MJ } \\
\text { cells under LILT } \\
\text { conditions }\end{array}$ & $\begin{array}{l}\text { - Test program to include } \\
\text { radiation } \\
\text { - Adapt cells/arrays to avoid } \\
\text { LILT problems }\end{array}$ \\
\hline $\begin{array}{l}\text { High Radiation } \\
\text { Missions }\end{array}$ & $\begin{array}{l}\text { Europa and } \\
\text { Jupiter missions }\end{array}$ & $\begin{array}{l}\text { Radiation resistance } \\
\text { with minimal weight and } \\
\text { risk penalty }\end{array}$ & - Thick cover glass & $\begin{array}{l}\text { - Concentrators } \\
\text { - Adapt commercial and } \\
\text { military rad-resistant cells to } \\
\text { LILT cell testing program }\end{array}$ \\
\hline
\end{tabular}

\section{ACKNOWLEDGEMENTS}

SGB would like to thank the members of the NASA Code $S$ technical assessment team of photovoltaic power experts and power system engineers, chaired by Rao Surampudi, for input and assistance. The committee members are Rao Surampudi (Chairman), Tom Hamilton (Coordinator), Donald Rapp, Paul Stella, Nick Mardesich, Jack Mondt, Bill Nesmith, Robert L. Bunker, Sheila G. Bailey, Henry B. Curtis, Mike
Piszczor, Ed Gaddy, Dean Marvin, and Larry Kazmerzki. We would also like to thank Dr. Ryne Rafaelle of RIT for information on IMPS, and David Scheiman for information on hightemperature solar array operation.

\section{REFERENCES}

1. G. Landis, S. Bailey, and B. McKissock, "Designing Power Systems," chapter 20, Human Spaceflight: Mission Analysis and Design, W.J. 
Larson and L. Pranke, eds., 643-664. McGraw-Hill Space Technology Series (1999).

2. G. Landis, S. Bailey and M. Piszczor, "Recent Advances in Solar Cell Technology," Journal of Propulsion and Power, Vol. 12, No. 5, 835-841, Sept-Oct. 1996. Paper AIAA-95-0027.

3. S. Bailey, H. Curtis, G. Landis, et. al., "Photovoltaic Technology Needs for Future NASA Science Missions," 17th European Photovoltaic Solar Energy Conference and Exhibition, Munich, Germany 22-26 October 2001

4. S. Bailey, G. Landis and D. Flood, "Photovoltaic Space Power: Status and Future," paper AIAA-98-1053, 36th Aerospace Sciences Meeting \& Exhibit, Reno NV, Jan 12-15 1998.

5. G. Landis, "Space Solar Array Technology 1997," SPS-97: Space and Electric Power for Humanity, Aug. 24-28, 1997, Montreal, Canada, pp. 125-128.

6. M. Kagan, V. Nadorov, S. Guha, J. Yang, and A. Banerjee, "Space Qualification of Amorphous Silicon Alloy Lightweight Modules," Proc. $28^{\text {th }}$ IEEE Photovoltaic Specialists Conf., pp. 1261$1264(2000)$.

7. G. Landis, "Solar Cell Selection for Mars," IEEE Aerospace and Electronic Systems Magazine, Vol. 15, No. 1, 17-21 (Jan. 2000). Presented at the 2nd World Conf. Photovoltaic Energy Conversion, Vol. III, Vienna, Austria, July 1998, 3695-3698.

8. R. Haberle, C.P. McKay, O. Gwynne, D. Atkinson, G. Landis, R. Zurek, J. Pollack and J. Appelbaum, "Atmospheric Effects on the Utility of Solar Power on Mars," Resources of Near Earth Space, pp. 799-818. U. Arizona Press Space Science Series (1993).

9. G. Landis and P. Jenkins, "Measurement of the Settling Rate of Atmospheric Dust on Mars by the MAE Instrument on Mars Pathfinder," $J$. Geophysical Research, Vol. 105, No. E1, pp. 1855$1857(\operatorname{Jan} 25,2000)$

10. D. Scheiman, G. Landis, D. Brinker, and V. Weizer, "High-Bandgap Solar Cells for Near-Sun Missions," Space Technology and Applications International Forum, AIP Conference Proceedings Volume 458, pp. 616-620, 1999

11. J. Randolph, ed. (1995) Solar Probe: Mission and System Design Concepts 1995, JPL Document D-13269.
12. S. Kerridge, et al. "Cost Effective Mission Design for a Small Solar Probe," Acta Astronautica, Vol. 35, Suppl., pp. 257-266 (1995).

13. G. Landis, "Review of Solar Cell Temperature Coefficients for Space," Proc. 1994 Space Photovoltaic Research and Technology Conf., NASA CP-3278, June, p. 385 (1994).

14. J. Fan, "Theoretical Temperature Dependence of Solar Cell Parameters," Solar Cells 17, pp. 309315 (1986).

15. S. P. Tobin et al. "Advanced Metallization for Highly Efficient Solar Cells," Proc. 19th IEEE Photovoltaic Specialists Conf., pp. $70-75$ (1987).

16. M. B Spitzer., et al. "Gallium Arsenide Concentrator Solar Cells with Highly Stable Metallization," Proc. 20th IEEE Photovoltaic Specialists Conference, pp. 930-933 (1988).

17. R. Raffaelle, S. Bailey, P. Neudeck, R. Okojie, C. Schanabel, M. Tabib-Azar, D. Scheiman, P. Jenkins, and S. Hubbard, "Optical and Electrical Characterization of SiC Devices, Proc. $28^{\text {th }}$ IEEE Photovoltaic Specialists Conf., pp. 1257-1260 (2000).

18. Panetta, et al., "NASA-GSFC NanoSatellite Technology Development", SSC98-VI-5, $12^{\text {th }}$ AIAA/USU Conference on Small Satellites.

19. R. Raffaelle, J. Harris, D. Hehemann, D. Scheiman, G. Rybicki, and A. Hepp,.. "Integrated Thin-Film Solar Power System", IAIAA-2000$2808,35^{\text {th }}$ Intersociety Energy Conversion Engineering Conf., Vol. 1, pp. 58-62, July 2000.R. Raffaelle, J. Underwood, P. Jenkins, D. Schciman, J. Maranchi, O. Khan, J. Harris, M. Smith, D. Wilt, R. Button, W. Maurer, and A. Hepp, "Integrated Microelectronic Power Supply", 36th Intersociety Energy Conversion Engineering Conf., Savannah GA, July 29-Aug. 22001.

21. D. Hoffman, R. Rafelle, G. Landis, and A. Hepp, "Mission Applicability and Benefits of ThinFilm Integrated Power Generation and Energy Storage," paper IECEC2001-AT-21, 36th Intersociety Energy Conversion Engineering Conference, Savannah GA, July 29-Aug. 22001.

22. Panasonic, Lithium Handbook, Sept. 2000.

23. S. Bailey et. al., "Photovoltaic Technology Needs for Future NASA Science Missions," 17th European Photovoltaic Solar Energy Conf. and Exhibition, Munich, Germany 22-26 Oct. 2001. 